\title{
Eastern Cape Bloodlines I: Assembling the Human
}

\author{
Nicky Rousseau
}

This is an article less about red as installation, colour or symbol, and more about assembly. ${ }^{1}$ I have used Red, the installation by Simon Gush, as provocation to think of exhumation, its work and processes of assembling-disassembling-reassembling. ${ }^{2}$ The particular exhumation discussed here involves the mortal remains of five anti-apartheid activists recovered at Post Chalmers outside the rural Eastern Cape town of Cradock in July 2007 by the Missing Persons' Task Team (MPTT). ${ }^{3}$ 'Topsy' Madaka and Siphiwo Mthimkulu, and Champion Galela, Qaqawuli Godolozi and Sipho Hashe (the 'Pebco Three') were killed in April 1982 and May 1985 respectively by Port Elizabeth security police, who thereafter burnt the bodies. 4

\section{Parenthesis 1}

This article too is a product of assembly-disassembly-reassembly. Written first as a conference paper on corporealities of violence, I later abandoned the unfinished article and then disassembled and re-assembled it for Red Assembly, with a different thematic in mind. Such an 'exhumation' from a graveyard of earlier papers ideas, or drafts will be familiar to many.

At the time of writing about corporealities of violence, I had in mind a provocation offered by Suren Pillay, whose dissertation critically examines how violence is figured in South Africa's Truth and Reconciliation Commission's (TRC) work. Dissecting the TRC's focus on the individual as locus both of suffering, defined as gross violations of human rights (the 'victim'), and of responsibility for such violation (the 'perpetrator'), Pillay proposes:

Apartheid has been seen as a set of gross violations of Human Rights, rendering the latter liable and the former opaque, and in the process normalizing one kind of violence while pathologizing another. We have therefore been moved to study the bodies, search their remains for traces of the state that might have been left at the scene of the violence. This is the forensic work performed in the production of a counter-narrative to the state. We have been looking for the state on the body, for its fingerprints and its presence... Death as a result of political violence in South Africa under apartheid has produced 'who' questions that simultaneously had readymade answers. 5 
The MPTT too was led to look for the bodies even though ten security policemen had confirmed the state's fingerprints in their admissions to the TRC's Amnesty Committee. Located in South Africa's official prosecuting authority, the MPTT also operated in certain respects within an evidentiary paradigm of fingerprints, clues and alibis. ${ }^{6}$ Following Pillay's provocation, does exhumation with its focus on the individual body of 'spectacular' violence necessarily operate within the same logic, producing the same 'who' questions and answers? While Pillay had transitional justice and law in his sights, his reference to 'the forensic work performed in the production of a counter-narrative to the state' implicates history as well. Gush and filmmaker James Cairn spoke about 'recovering' the workers' voice from the company's narrative of the Mercedes Benz gifted to Nelson Mandela as emblematic of its successful transformation (and, by extension, the nation's) through a social pact of capital and labour. Gush also spoke of the trade union's mode as always to say 'go speak to so and so', evoking an archive of voice.7

In exhumations, bodies or skeletal remains are retrieved from formal or informal graves. Thereafter they are forensically examined to establish identity. Similarly, we could think of the body as archive and exhumation as a recovery project. Are exhumations also a recovery project, not dissimilar to recording and writing 'hidden histories', recuperating 'silenced voices'? Would a scrutiny of the practice of exhumation replicate the well-worn critiques of recovery and social history? 8

\section{Parenthesis 2}

In the film by Gush and Cairn, we learn of the work of assembling a car, $\underline{t}$ his car, the gift, a red Mercedes Benz. In Gush's opening remarks we learnt of how the installation's semi-assembled Benz had been retrieved, 'exhumed' from a scrapyard, stripped and disassembled, leaving only the 'body' and how each installation involves multiple processes of assembly-disassembly-reassembly.

Viewing exhumation's work through the lens of corporealities had led me to conclude that attention to the corporeal amassed an excess: sedimented layers of violence, rather than the 'who questions with readymade answers' suggested by Pillay. Producing a 'counter-narrative to the state' required considerable work. While a focus on the corporeal brought the body of those who exhume into view and the ways in which a body is less recovered than produced, 9 it seemed less deft in grasping rehumanization. ${ }^{10}$ This discontent produced fertile ground to take up a further provocation offered by conference organizers. Posing the question of recovery alongside the particular manner in which Gush had assembled Red, they asked: "What does it mean to assemble, what is the work of assemblage, how is work assembled? ${ }^{11}$ 
There are several ways of thinking 'bloodline' in relation to these killings and exhumations. Bloodline, of course, evokes red blood: this is one of few links to the prompt 'Red'. There is indeed an excess of bloody violence in these particular bloodlines. One bloodline, or lineage, would connect the five men to resistance histories, in particular to the abductions and killings of Mathews Goniwe, Sicelo Mhlauli, Sparrow Mkonto and Fort Calata, the 'Cradock Four', who disappeared seven weeks after the 'Pebco Three'. Unlike the 'Pebco Three', security police left their bodies, variously shot, stabbed and bludgeoned, close to the road. ${ }^{12}$ Their funeral in a stadium in Lingelihle township outside Cradock, attended by an estimated 70 ooo activists from across South Africa, took place not just under the United Democratic Front's black, red and yellow and the banned ANC's black green and gold flags, but for the first time in decades under the 'deepest red' of the banned South African Communist Party. ${ }^{13}$ 'The People's Flag' and 'The Internationale' surely counted among the struggle songs comrades, and especially the youth, or 'young lions', 14 roared out in their imagined forward march to a 'red' future of equality and prosperity.

Through these deaths, these men become part of longer bloodlines, joining a pantheon of heroes who lost or 'gave up' their lives. We could think of this lineage as 'representing the many people that have spilled blood in this country to liberate it, to bring it to liberation', as suggested by Mandela on receiving the Benz, and thus on whom the nation is said to rest. ${ }^{15}$ An opposite bloodline would trace the perpetrators' lineage.

The killing site itself offers another bloodline. Situated on the banks of the Pauls River, a tributary of the Great Fish River, Post Chalmers' history is associated with bloody wars of land dispossessions in the Eastern Cape in the late eighteenth and nineteenth centuries, in which the Great Fish River figured as a shifting boundary between colony and Xhosa. As David Bunn has pointed out, these wars were also wars on the corpse 'in which the body itself, torn apart, limbs sundered or mutilated, had become a significant means of communication between warring sides'. ${ }^{16}$ In 1860 the colonial government established a police station named Post Chalmers as a measure to curb 'stock theft'. ${ }^{17}$ This occurred at a precise historical juncture, some four years after a young Xhosa seer, Nongqawuse, prophesied the white settlers' defeat and a new world of abundance for the Xhosa. Thousands of largely unconverted, or 'Red' Xhosa (invoked in the article by Minkley and Pohlandt-McCormick), worn down by war, drought and cattle disease heeded her call to destroy crops and cattle. The subsequent 'Great Cattle-killing' is seen to have accomplished what colonial warfare had failed to - break the power of Xhosa polities, hastening the process of turning their people into labourers on white farms, and later the mines. ${ }^{18}$

War again came to the very doors of Post Chalmers during the South African War (18991902) when Boer guerrillas 'wrecked the place [...] and [British] columns [...] did the 
rest'. ${ }^{19}$ Later rebuilt, the police station continued to operate until the 1970 . Thereafter Post Chalmers became a safe space for covert operations. Port Elizabeth security police took at least nine activists there: just one survived, after turning informer. When perpetrators disclosed these killings to the TRC's Amnesty Committee, the families journeyed to Post Chalmers, stopping at a spot on the Great Fish River where the burnt remains were allegedly thrown. To see the families offering flowers to their dead on this most historic of rivers is to feel time collapsing, folding back these more recent killings into that long century of war. The local farmer who bought the property in the 1990 s subsequently made several transformations to the killing ground, re-purposing it as children's holiday farm, private home for his son, abattoir and hunters' lodge.

A much longer lineage of the land is contained in the Archaeological Contracts Office's report commissioned by the MPTT:

Being on the edge of the karoo, the topography of the area consists of plains, eroded river valleys with intermittent hills and dykes [...] formed from volcanic extrusions of dolerite (similar to granite) which pushed through the shales of the karoo in ancient times. $^{20}$

Bringing the archaeologist's narrative mode to a whitewashed settlement next to an almost dry riverbed, this was an account of material land. The history Hart evoked was of 'ancient times', the longue duree of the earth's slow transformations by volcano, rain and wind, followed by a more recent history of buildings, water and sewerage systems, leading to these singular events, and requirements for 'safe burial':

This means that options for burial of human remains are fairly confined, as the safe burial of a body would require in excess of a meter of soil depth which can be dug by hand (with shovel) without mechanical assistance. ${ }^{21}$

These different bloodlines all come to bear on the five men, but the bloodline I turn to now is one associated with exhumation and identification. The latter in such cases is exhumation's very raison d'etre, resting on the lineage of family, of blood-relations. We think of blood as flowing, and transfer this image to the bloodlines on a family tree. Here I want to think of them as assembled, just as the bloodlines sketched above are assembled.

\section{Exhumation's work ${ }^{22}$}

Day One - Two, 9-10 July 2007.

Assembled in the kitchen of the station-commanders house, most recently occupied by the Van Heerden family, the MPTT team spends some time mapping landmarks from an unedited video interview and some photographs. Both show TRC amnesty applicant, Gideon Niewoudt, identifying the burn sites. The forensic team proposes to 
clear the stony gravel across the backyard, pump the contents of two septic tanks within the backyard's boundaries, and clear an adjacent ash-pile.

The interview and photographs also provide visual evidence of extensive alteration in the intervening period when the young De Villiers' family inhabited the house: fencing, grass, stony gravel, and a crude cement swimming pool. The archaeologists are banking that the fires' intensity left a blush, a reddening or rubification, through several layers of soil. The possibility of finding more than a few fragmented bones seems bleak and improbable.

Work soon normalizes space, transforming even violent places: the kitchen and lounge, sites of alleged interrogation and probable torture, become just a kitchen and lounge, places for making tea, storing lunchboxes, and later a place where families of the missing men would assemble. Similarly, the backyard becomes a site of ordinary manual work activity, filled with everyday items, 'tools of trade' of the discipline of archaeology, brooms, spades, trowels, brushes, and the accompanying sounds of digging, scooping and sweeping.

Day Three, 11 July 2007.

The ash pile has been ruled out, as have two small pinkish patches of sand, named BP (Burnt Patch) 1 and BP 2. Despite initial low expectations of success, the mood is gloomy.

Non-forensic team members, accompanied by a worker, Shadrack Ben, trek across the property, which only demonstrates the difficulties of mounting a wider search. Our pessimism deepens when we hear that a faint pink spot behind the garage and under the pepper tree, where we had left archaeologist Tim Hart, slowly, almost meditatively, sweeping the ground, was the exact location where a night watchman had routinely built a small fire. We return to find Hart still at the same spot, with other forensic team members now, where that faintest of pink - evidence of rubification - has deepened. A thin darker line emerges, then a small trace of ash appears, like a fuse running along the ground, to what, as layers of sand were removed, is a pit of burnt material. The tension ratchets up until what at first glance looked like a very large braaivleis (barbecue) site reveals a mixture of ash, burnt wood, tyre, glass and bone, human bone. ${ }^{23}$

Day Four, 12 July 2007.

An energized team begins further exposing the burn site, BP3. Once fully exposed, it is two by three metres in diameter, approximately twenty centimetres deep. Team members begin the work of sieving its contents, also a work of classification. Once sieved, remaining bone, artefacts (zips, buttons, coins, bottles), wood and tyre are sorted into different piles.

Van Heerden (Snr) arrives bearing a rudimentary pump. He and several workers improvize a mechanism to pump the septic tank's contents onto a crude sieve of mesh 
placed in the riverbed behind the property. Raw decomposed sewage is pumped from the first compartment, ST (Septic Tank) 1 and washed through mesh with a hose. Soon the consistency changes, becoming thicker, oilier, with the unmistakeable smell of diesel. The pump slows, becoming sluggish, ejecting a sludge containing material similar to that in BP3: burnt wood, diesel-coated ash, a cheap ring, some keys and once again human bone, which is separated by hand, washed carefully and left to dry on the riverbank.

Family members of the men journey from Port Elizabeth, arriving in the afternoon. Team members explain and identify pieces of bone, showing retrieved artefacts. Family members walk around the site; they touch, pick up and hold material, a few look for bone themselves. Mostly there is quiet talking, holding hands, supporting one another, some tears. A local priest says a prayer before they depart.

Day Five, 13 July 2007.

Everything from the site - bone, bottle, wood fragments and artefacts as well as the sieved sand and ash - are packaged and labelled. The cardboard boxes and large plastic bags are loaded onto the truck destined for the MPTT's Pretoria offices.

6-10 August, 2007.

One month later, the team returns to complete the excavation. The Cradock municipality provides a 'honey wagon' to drain the septic tank's second compartment, ST1-2. When opened, the smell of diesel is immediate. The contents, transported to the local sewage works, again yield considerable bone and artefacts. The backyard is trenched with a small mechanical excavator, and a tiny rubifed patch, $\mathrm{BP}_{4}$, is located adjacent to the septic tank. Only a few bone fragments are found. The families return again, spending some hours on site, listening, watching, touching.

\section{Producing the body of mourning}

Those exhuming suggest that putting spade to ground is the culmination of research and investigation, ${ }^{24}$ falling somewhere between the work of the historian, lawyer and policeman, conducted over months or years. This is work of assemblage directed towards producing a case file with textual evidence.

Exhumation, however, is different: its disciplines are archaeology, anthropology and anatomy. Its practice of investigation is often sensorial, relying on an intimate interaction with the ground and body. It is work, which is slow, careful, scrupulous, becoming increasingly delicate as the diggers get closer to physical remains. Spades are replaced with trowels and brushes. Combining the forensic crime scene's practices with archaeology, skeletal remains are labelled in situ with markers and rulers before being removed, bone by bone, and placed in labelled packets. Each stage is photographed. At Post Chalmers 
much of this was impossible. Instead a more basic exercise of sieving, retrieving and separating material took place; a process conducted in the teeth of a biting wind, blowing dust and dispersing ashy material into air and eyes, leaving a thick rim around the bathtub at night. In all, two hundred and sixty kilograms of assorted material was removed from the site for further examination. Of this ' 12.6 kilograms of burnt human bone fragments were recovered from the two fire sites ( $\mathrm{BP}_{3}$ and $\left.\mathrm{BP}_{4}\right)$ and the nearby underground septic tank comprising two compartments (ST1 and ST1-2), ${ }^{25}$

What constitutes the body? How much? ${ }^{26}$ At a TRC hearing, Joyce Mthimkulu held up a fistful of her son Siphiwo's hair that she had kept as evidence of thallium poison during an earlier detention. Later, she had buried the hair, the only remainder of her son's physical body, in a burial ceremony in her yard. ${ }^{27}$ The fragments subsequently recovered at Post Chalmers were more reminders than remainders.

Technologies of identifying mortal remains on site happen in part through physical apprehension of ground and body - colour, appearance, texture, smell and an intimate understanding of both soil and body's transformations. ${ }^{28}$ This apprehension passes from earth and mortal remains to the anthropologist or archaeologist's living body, an interaction or transference that brings the latter to view. This lack of attention to the agent exhuming occludes the process through which, as Zoe Crossland reminds us, a dead body is produced, rather than recovered. ${ }^{29}$ In some cases, interaction between the living and the dead produces a body of evidence for the court or a body to mourn. ${ }^{30}$ In both cases, multiple techniques and processes produce the human body.

Crossland suggests the human skeleton, especially the skull, evokes a human body. ${ }^{31}$ Yet this obscures the assemblage of physical skeleton and acts of 'speculative reconstruction'. Skeletal remains, even when saponified or disarticulated, are somewhat incorporeal, existing between the corporeality of the body and the dust and carbon particles they are destined to become. Without a largely affective identification, 'speculative reconstruction' could equally produce skeletal remains as mere carbon particles, or summon up more ghoulish or ethereal incarnations. To embody, to evoke the corporeal body, the beloved's body, is an act directed at rehumanization. ${ }^{32}$ This requires stabilizing work to end speculation, a process facilitated and encouraged by the living bodies of anthropologist or archaeologist. This is effected through multiple means - physical acts of care and respect in handling bones, the naming of parts, readings of age, gender and, yes, race, 33 distinguishing features such as height, build, teeth and cause of death.

Adam Rosenblatt, discussing the 'intimate material contact' that forensic teams have with dead bodies, cites EAAF's Mercedes Doretti as '[describing] gluing the pieces of a skull back together as a form of "reparation". 34 Certainly, watching practised hands delicately removing bones, naming and placing them carefully in labelled paper bags, is central to 
producing the human body, constructing at the same time, as both medium and effect, a community of mourning and care. Although the procedures meticulously present themselves as science, they are profoundly affective too. 35

The work of rehumanization, however, is challenged where bones are dismembered, commingled or extensively damaged by fire. At Post Chalmers little distinguished the human in the burnt residue from $\mathrm{BP}_{3}$, or sludge pumped from ST1 and 1-2. Here, there were no labelled paper bags. Nonetheless, sieves caught significant bone material from both ashy pit and sludge from the septic tank. The human emerged through trained eyes, more so when possible to name a part.

Death and funerary practices are also about disassembling the human from the animal. 36 Rehumanization thus rests on the identification of human bone. Post Chalmers challenged this separation. While the MPTT worked to retrieve remains of humans shot and braaied like animals, the slaughtering of animals proceeded in the adjacent farm abattoir, once an old-cell block in which human suspects had been incarcerated. Andre van Heerden (Snr's) daughter, an art student, produced an artwork arising from the tension between the home of her youth and its histories of violence; in her accompanying essay she commented on the breaching of the boundaries of captivity and the human-animal. $37 \mathrm{We}$ occasionally heard sounds of animals: walking past the abattoir, I encountered a young cow tethered on its side, eyes rolling, terrified, in the back of a bakkie (a pickup truck). Animal bone littered the banks of the river-bed.

If recognizing bone was central to identifying the human, artefacts assembled the idea of a more fleshed, corporeal body. A shoe or zipper fragment, shoelace, button, buckle, a door key, some coins: these were more agentive in assembling the human persons, just as tyre, diesel, bullets, beer bottles, summoned their killers, suggesting the human is held together less by physical body, but assembled through fragments, things or objects, sensorial and affective. 38 It was hard not to summon up Mthimkulu and Madaka dragged from their car, or the three Pebco men hastening to their rendezvous at the airport from where they were abducted. Conversely, brown glass - the colour of Carling and Lion beer bottles bullets, burnt tyre fragments, summoned Nieuwoudt and his men.

The place and role of the family in exhumation and rehumanization is even more occluded than that of those who exhume. Yet it is arguably crucial for teams such as the MPTT whose work is undergirded by notions of reparation. Encounters described earlier when family members were on site demonstrate the family is not just recipient. Rather, its physical or metaphorical presence and agency may be required for the production of the mournable body and associated community of care. If as, Rosenblatt suggests, those who do exhumation's work do the task most would dread - digging up the dead, then this capacity is in part sustained and produced by the reciprocal work of family. 39 


\section{Producing this person}

To end the uncertainty said to haunt families of the missing, to stabilize transformation from liminal to mournable body, requires individual identification, or what Jenny Edkins would refer to as accounting for this human, 'the person-as-such'. ${ }^{40}$ Everything is directed towards this: reburial by family or body of evidence in court rests upon identification. Pre-mortem interviews are always directed towards this person, their height and build, a family photo, this fall when a bone was broken, a tooth lost, a training injury. In reverse, in the quest for individual identification, photographs pass hands from investigators to family. Such transactions enable a narrative construction of personhood to be assembled, what Rassool calls an 'extension of the biography of the dead', ${ }^{41}$ although for families this biography may also be a process of dismembering remembered personhood.

The MPTT describes identification as a project of global citizenship, noting that, in contrast to a growing norm of recovery, millions of families across Africa continue to live in limbo, unable to occupy the new sense of citizenship that is the promise of newly emerging democracies [...] (leaving) Africa's dead [to] remain largely unaccounted for [...] [They] continue to exist in the public imagination of the rest of the world as faceless and nameless, mere suffering masses, reflecting wider philosophical and political issues relating to racialized global citizenship. ${ }^{42}$

It is in a laboratory, through forensic techniques, that approximate identifications are transformed into greater certainty where possible - genetic lineage and identity. Rehumanized during exhumation, the human arrives in the laboratory, separated and packed into labelled paper bags. They are just so many bones: rehumanization must begin afresh. In part this is effected through the laying of bones in anatomical order, enabling forensic teams to reconstruct biography, noting signs of identification and cause of death. The 'person-as-such' is produced through interpreting demographic markers and unique biographical events. In the Post Chalmers case, possibilities of individual identification were always improbable. Identification rested more on identifying these as the group being sought, but thus far this link had only been established by, and was tethered to, the killer's TRC testimony.

Forensic examination began in May 2008, directed by Steve Symes, a burns expert from the United States. Over seventy tooth roots and crowns had been extracted from the recovered material. A forensic odontologist identified at least three adult males from $\mathrm{BP} 3$ and at least one adult male from each of ST1 and ST 1-2. From this, a hypothesis was formulated: $\mathrm{BP}_{3}$ was the 'Pebco Three's' pyre, while $\mathrm{BP}_{4}$ was the probable location of Mthimkulu and Madaka's, whose burnt remains had then been scooped into the septic tanks.

Here there were no packets, only commingled remains. The team of bone experts separated identifiable bone from fragments impossible to name. Identified bones were 
placed in anatomical position on three tables corresponding to BP 3, ST1 and ST1-2. These resembled bizarrely distorted human bodies; some sections of the skeleton packed densely, others barely visible. The work was painstaking, a jigsaw puzzle to be assembled with no accompanying picture, washed in greys, charcoals and black.

Symes then prompted them to "work backwards from the post-mortem condition, understand how heat alters tissues, and eventually work to put...flesh back on the victim'.43 Symes had taken the team through the science of fire, and provided three important clues - colour, body-position and shielding, and the biomechanics of burned bone fracture. As flames engulf the human frame, drying bone and shrinking muscle fibres, muscles, tendons and ligaments contract. The body assumes the 'pugilist stance' crouched, hands up as though boxing. Such contractions expose some areas, while shielding others. 44 In the common pugilist position, shielded bones are last to fracture and disintegrate, thus least damaged and most recognisable. 45 Looking down at the strange anatomical shapes on the table, it was clear that little remained of the pelvic area. These were precisely commonly shielded parts and their absence suggested some human remains had probably been removed from the site, and dumped elsewhere, perhaps in the Fish River as indicated by amnesty applicants. If so, it points to the difficulties of obliterating all traces of the human body in such covert killings.

The findings of the forensic anthropologists concurred with the odontologist's. The 'Pebco Three' families would collectively receive the remains found in BP3. Those from BP4 and ST1 and ST1-2, would be given to the Mthimkulu and Madaka families. This was better than the team had hoped for: corresponding to events, two groups-as-such.

\section{Parenthesis 3}

Nicky, ... I was so struck by ... you know that confessional opening, of 'I didn't write about the piece [the disassembled Benz], I just felt anxious about the piece, I couldn't 'see' the piece' - and then in the course of things it seemed to me that you discovered that you were fully engaged with the piece. [Laughter] Exactly! And, so there is something very unusual it seems to me, and perhaps quite instructive about the relationship between art and history - that you don't see it, but it's there, you read these sites, you, as you point to, you produce bodies, right, there is something completely continuous with [it].46

Despite failing to produce individual identification, this can be read as a moment of stabilization, facilitating the return of mortal remains, enabling the healing and closure on which the claims of transitional justice rest. Yet the MPTT recovered not subjects, nor even bodies, but fragments, demonstrating not recovery but its impossibility. An exclusive focus on the body exhumed, without attention to those doing the exhuming, occludes the production of the body and the extent to which this is a transfer not from one party, but an assemblage of exhumer, dead body, family, things and disciplinary knowledges. This assemblage is by no means stable or predictable, enabling what conference organizers, following Deleuze and Guattari, suggest are different 'lines of flight'. 
Engaging the bloodline of identification and rehumanization here follows one such line of flight', and in doing so assembles an archive, a process that itself is one of assemblydisassembly-reassembly.

\section{Red, the installation; Red, the politics}

We could similarly ask: 'what is being assembled, disassembled and re-assembled in Red?' Or, 'what is the symbolic giving of this thing (the car, the installation, the story)?'47 What appeared to be directed at disassembling the Benz as symbol of the dominant, and in its place instating the recuperated voices of workers, turns out to be more ambivalent.

Gush, through disassembly-reassembly of the Mercedes Benz, brings to view the labour that must be expended to create its sleek, smooth experience. In the film, we hear traces of the work on Mandela's Benz - also careful, scrupulous, presented for inspection with an unheard of 'only six faults... perfect'. ${ }^{48}$ Yet, this work is not just labour, or rather labour is not just work: in the film Gush and Cairn also re-instate the strife, artistry, desire and jealousy that is part of motor assembly, even as workers produced Mandela's Benz. We find the assembly of this red Benz has been accompanied by disassembling red in a subsequent strike: riven into factions, its solidarity and life-blood drains onto the factory floor. Does the disassembled Benz gesture towards a 'new South Africa' in which the possibilities of a red revolution will be disassembled, in which the red blood of sacrifice, as suggested by Mandela, will have been betrayed and revealed to be 'blood money' not 'blood sacrifice'? Or: Perhaps an irony that it is NUMSA workers, the vanguard who carried the 'bloodline' of radicalism and a dreamed of red revolution, who - long before negotiators sealed compromises, long before the embrace of a neo-liberal economic path chose to honour the newly released Mandela with the very symbol of capitalist excess?

Or: A moment in the film when Thembalethu Fikizolo contemplates the bitterness of a shop steward excluded from an industry-wide bargaining structure who had subsequently led the ill-fated strike. I am struck by the time and detail he provides in building to this moment, a single moment of a quieter, more reflective self. Its effect, although unintended, is searing, burning through layers of political rationalities, of revolutionary fervour or capitalist cunning, instating instead an altogether more mundane rationality of status, humiliation and slight. By instating the human person, the person-as-such, in place of the proletariat, its effect is also to rehumanize.

Mark Sanders, commenting on many TRC testimonies referring to violated and missing bodies, of funerals disrupted by police violence, contends that apartheid can be understood as a proscription on mourning. 49 This argument is elaborated through the figure of Mthimkulu's mother holding up a fistful of her son's hair, calling attention to the importance of physical remains. Following this, political violence's body, does not, cannot escape the binds of apartheid or nationalism. ${ }^{50}$ 
Reading Jenny Edkins alongside Sanders, if the proscription on mourning is apartheid, then it rests on 'bare life's' very in-distinction: Africa's anonymous and suffering dead to which the MPTT refers were apartheid's very condition. Edkins suggests that in making evident the 'radical relationality of life', missing persons demonstrate the limits of sovereign power. In just the way that missing persons radically disrupt the lived temporality of families left behind, who exist simultaneously 'turned backward to the past and.... turned toward the future', $5^{1}$ they challenge the linearity on which sovereign power rests, opening a space for politics. Against a form of politics that 'misses the person [...] that objectifies and instrumentalizes', Edkins argues for a politics that asserts 'the one' that must count, 'the person-as-such'. ${ }^{2}$

After the Post Chalmers excavations, $12.6 \mathrm{~kg}$ of human remains were distributed across two coffins and returned to families for reburial. These mournable bodies were celebrated as heroes of the nation in ceremonies attended by high profile political leaders, demonstrating the body's ongoing instability. 53 In South Africa, the ceremonial practices following exhumation and identification lead back to the warm embrace of nation and nationalism. Such moments are desired and sought after by families themselves; elsewhere I have argued that for families such moments serve as a reminder to the governing party that the sacrifice made by the deceased - and by extension the family - to a 'nation yet to be has not been reciprocated in the nation now present [...] [The] insistence on the unfulfilled promise of the nation now present is one disabling or refusing closure. 54

In his comments at the conference, John Mowitt noted:

There's a quite important concept in Marx, that of dead labour. And what is dead labour? Dead labour is the exertion of labour power, the time of its exertion, and that is, in fact, contained in the object. So in effect the car is a site of exhumation; it always is - even the car that is fully intact and roaming around in East London. So that there is something very direct and explicit here about the connections being made between exhumation and assemblage and disassemblage. I think the issue then becomes one of: what is the significance of the exhumation of this dead labour? In effect Marx is concerned about it because it produces the sort of fortification of the object that stands against, that weighs down on labour. That dynamic seems to be interestingly jostled in this conversation. 55

If, for Marx, dead labour 'weighed against' living labour, how do we understand a politics in the aftermaths of an imagined red future, in which dead labour is explicitly invoked to speak politically, as a reminder-remainder of an imagined future and the work done towards that future? We could say families exhume, just as Gush seeks to in his installation, the 'dead labour' of struggle, precisely to weigh against the present as both reminder and remainder - not merely as foundation of nation, consigned to the past - but as living and present. Following this we could ask whether such a politics, which poses 
the question of disappointment, is able to disassemble the sleek narratives of transition and the social pact of business, government and labour, and to insist stubbornly for a politics that does not objectify and instrumentalize.

\section{Disclosure statement}

No potential conflict of interest was reported by the author.

\section{Notes}

1. I was previously a research consultant for the Missing Persons Task Team, and coinvestigator in the Post Chalmers cases.

2. On background to Red and Red Assembly, see the editors' introduction to this issue.

3. The MPTT is a unit mandated by government to investigate the fate and whereabouts of missing persons cases from the TRC.

4. Mthimkulu and Madaka were 'disappeared' on 14 April 1982, the Pebco Three on 8 May 1985.

5. Pillay, "The Partisan's Violence," 43.

6. On the evidentiary paradigm, see Crossland, "Of Clues and Signs," 69-80.

7. Gush and Cairn at Red Assembly, the conference.

8. This is a critique evident in my own work. See Rousseau, "Popular History."

9. Crossland, "Of Clues and Signs," 69. See also Colaert, "Not Just Bones", 105.

10. Layla Renshaw, in her excellent study, tends to refer to this as rematerialization. See Renshaw, Exhuming Loss, Chapters 3 and 4.

11. Gush et al., "Red Assembly," 5.

12. Pillay, "The Partisan's Violence," 21-24.

13. Seekings, The UDF, 148.

14. 'Roar, young lions, roar!' was a common slogan in the mid-1980s, directed at youth activists.

15. Rousseau, "Identification, Politics, Disciplines," 190.

16. Bunn, "Morbid Curiosities," 42.

17. De Klerk, "Post Chalmers, Bied Geen Rus vir Spook", Die Burger, http://152.111. 1.87/argief/berigte/dieburger/1997/02/22/4/ 9.html; "Post Chalmers Steeds Bloederige Slagveld," http://m24arg02.naspers.com/ argief/berigte/dieburger/2004/03/30/OB/9k/ 01.html. Accessed 29 February 2016. Thanks to Noëleen Murray for these references.

18. Peires, The Dead Will Arise; Bradford, "Women, Gender and Colonialism," Mda, Heart of Redness.

19. Inspector F. Gillwald to the Commissioner of Police, King William's Town, 18 November 1902, PWD 2/1/82 A8, Cape Archives.

20.ACO, "Inspection," para 4.

21. Ibid, para 7 .

22. This reconstruction relies heavily on memory. Members of the team (myself included) remember the events in sharply differing ways. MPTT members involved in the investigation, exhumation and/or laboratory analysis were: Claudia Bisso, Madeleine Fullard, Tshiamo Moela, Sipiwo Pahlane. Other persons involved in the 
exhumation and/ or laboratory analysis were: Kavita Chibba, Genevieve Dewar, Kundi Dembetembe, Nonhlanhla Dlamini, Jacqui Friedling, Hope Gangata, Dave Halkett, Tim Hart, Phillip Hine, Natalie Keough, Ericka L'Abbe, Thabang Manyaapelo, Morongwa Mosothwane, Laché Rossouw.

23. Renshaw describes this moment on an exhumation site as follows: "The site takes on a somber atmosphere, with a tangible thrill of anticipation...There is a respectful and solemn silence at the site in response to the first materialization of human remains, and the new presence of the dead among the living." Renshaw, Exhuming Loss, 149.

24. See http://eaaf.typepad.com/investigative_training/. Accessed on 9 February, 2016. MPTT, "Report," 2.

25. Following 9/11, fragments of identified human remains were returned to families. In contrast, in Bosnia, bodies spread across secondary and even tertiary graves were initially only handed over once $70 \%$ of the body has been identified. Weizman, "Introduction," 25.

26. Kaplan, Between Joyce and Remembrance.

27. Fontein and Harries, "Human Substances."

28. Crossland, "Of clues and signs," 69.

29. Laqueur, "The dead body and human rights."

30.Crossland, "Of Clues and Signs," 73.

31. Rousseau, "Identification, Politics, Disciplines"; Rassool, "Human remains." Also see Karl, "Rehumanizing the Disappeared."

32. This is controversial, although forensic anthropologists argue 'race' indexes ancient, ancestral populations, rather than how race is currently understood. See Rosenblatt, Digging for the Disappeared, 14- 15 and fn47.

33. Rosenblatt, "International Forensic Investigations," 927.

34. Crossland, "Of Clues and Signs," 73; Renshaw, Exhuming Loss, 41-42, Rosenblatt, Digging for the Disappeared, 28.

35. Posel and Gupta, "Life of the Corpse,"

36.301; Laqueuer cited in Honig, "The Other is Dead," 149-150.

37. Personal communication. See also Renshaw, Exhuming Loss: 147- 184.

38. Rosenblatt, "International Forensic Investigations," 925.

39. Edkins, Missing: Persons and Politics, 1-14.

40. Rassool, "Human Remains," 142.

41. MPTT, "DNA Laboratory: Concept Proposal," para 3.

42. Schmidt and Symes, Analysis of Burned

43. Human Remains, 50.

44. Ibid., 30.

45. Ibid., 44-49.

46. John Mowitt at Red Assembly, the conference. Author's transcription.

47. Ibid., 5 .

48. Christoph Köpke in Red, the film.

49. Sanders, Ambiguities, 34-58.

50.Moosage, "Missingness." 
51. Apologies to Giorgio Agamben who uses this in a quite different context, "The Time that is Left," 1. For those left behind, temporality is most frequently represented as 'frozen' or 'stuck'. This seemed more apposite.

52. Edkins, Missing: Persons and Politics.

53. For instability of body, and heroism, see Verdery, Political Lives; Renshaw, 204-211; Rousseau, "The Farm, the River and the Picnic Spot: Topographies of Terror." 54. Rousseau, "Politics, Identification, Disciplines," 193.

55. John Mowitt at Red Assembly, the conference. Author's transcription. 


\section{Bibliography}

Agamben, Giorgio. "The Time that is Left." Epoché 7, no. 1 (2002): 1-14. doi:10.5840/ epoche2002714.

Archaeology Contracts Office (ACO). "Inspection by Archaeologist of Post Chalmers, Cradock District," 11 September 2006.

Bradford, Helen. "Women, Gender and Colonialism: Rethinking the History of the British Cape Colony and Its Frontier Zones, C. 1806-70.” Journal of African History 37, no. 3 (1996): 351-370.

Bunn, David. "Morbid Curiosities: Mutilation, Exhumation and the Fate of Colonial Painting." Transforming Anthropology 8, no. 1\&2 (1999): 39-53. doi:10.1525/tran.1999.8.1-2.39.

Colaert, Lore. "Not just bones': A cultural and political history of mass grave exhumations in Spain." In Heritage Re-invents Europe: Proceedings of the Internationale Conference Ename, Belgium, 17-19 March 2011, edited by Dirk Callebaut,

Jan Marǐ ḱ ova and Jana Marǐ ková-Kubková. Ename: Europae Archaeologiae Consilium (EAC), 2013. https://biblio.ugent.be/publication/5761284/file/5761410.pdf. Crais, Clifton. White Supremacy and Black Resistance in Pre-Industrial South Africa: The Making of a Colonial Order, 1770-1865. New York: Cambridge University Press, 1992.

Crossland, Zoë. "Of Clues and Signs: The Dead Body and its Evidential Traces." American Anthropologist 111, no. 1 (2009): 69-80. doi:10.1111/j.15481433.2009.01078.x.

Edkins, Jenny. Missing: Persons and Politics. New York: Cornell University Press, 2011. Fontein, Joost and John Harries. "The Vitality and Efficacy of Human Substances." Critical African Studies, 5, no. 3: 115-126. doi:10.1080/21681392.2013.847660.

Gush, Simon, Leslie Witz, Gary Minkley and Helena Pohlandt-McCormick. "Red Assembly - Time and Work: A Workshop Proposal." 2014.

Honig, Bonnie. "The Other is Dead: Mourning, Justice and the Politics of Burial." In Theorizing Post-conflict Reconciliation: Agonism, Restitution and Repair, edited by Allexander Keller Hirsch, 149-165. Oxford: Routledge, 2012.

Kaplan, Mark J. Between Joyce and Remembrance. DVD. Directed by Mark J. Kaplan. Grey Matter Media, 2004.

Karl, Sylvia. "Rehumanizing the Disappeared: Spaces of Memory in Mexico and the Liminality of Transitional Justice." American Quarterly 66, no. 3 (2014): 727-748.

Laqueur, T. "The dead body and human rights." In The Body, edited by Sean Sweeney and Ian Hodder, 75-93. Cambridge: Cambridge University Press, 2002. Mda, Zakes. The Heart of Redness. New York: Picador, 2003.

Missing Persons Task Team (MPTT). "Report: The Search for Missing Activists at Post Chalmers near Cradock, Eastern Cape.” August, 2009.

Missing Persons Task Team (MPTT). "DNA Laboratory: Concept Proposal." July, 2007. Moosage, Riedwaan. "Missingness, History, Apartheid-Era Disappearances." PhD diss., University of the Western Cape, in process. 
Peires, Jeff. The Dead will Arise: Nongqawuse and the Great Xhosa Cattle-Killing of 1856-7. Second Edition. Jeppestown: Jonathan Ball Publishers, 2003.

Pillay, Suren. "The Partisan's Violence, Law and Apartheid: the Assassination of Matthew Goniwe and the Cradock Four." PhD diss., Columbia University, 2011.

Posel, Deborah, and Pamila Gupta. "The Life of the Corpse: Framing Questions and Reflections." African Studies 68, no. 3 (2009): 299-309.

Rassool, Ciraj. "Human Remains: Disciplines of the Dead and the South African Memorial Complex." In The Politics of Heritage in Africa: Economies, Histories, Infrastructures, edited by Derek R Petersen, Kodzo Gavua and Ciraj Rassool, 133156. Cambridge: Cambridge University Press, 2015.

Renshaw, Layla. Exhuming Loss: Memory, Materiality and Mass Graves of the Spanish Civil War. Walnut Creek: Left Coast Press, 2011.

Rosenblatt, Adam. Digging for the Disappeared: Forensic Science After Atrocity. Stanford: Stanford University Press, 2015.

Rosenblatt, Adam. "International Forensic Investigations and the Human Rights of the Dead." Human Rights Quarterly, no 32 (2010): 921-950.

Rousseau, Nicky. "The Farm, the River and the Picnic Spot: Topographies of Terror." African Studies 68, 3 (2009): 351-369.

Rousseau, Nicky. "Identification, Politics, Disciplines: Missing Persons and Colonial Skeletons in South Africa." In Human Remains and Identification: Mass Violence, Genocide and the 'Forensic' Turn, edited by Elisabeth Anstett and JeanMarc Dreyfus, 175-202. Manchester: Manchester University Press, 2015.

Rousseau, Nicky. "Popular History in South Africa in the 1980s: the Politics of Production.” M.A. diss, University of the Western Cape, 1995.

Sanders, Mark. Ambiguities of Witnessing: Law and Literature. Stanford: Stanford University Press, 2007.

Schmidt Christopher W. and Stephen A.Symes. Analysis of Burned Human Remains. Second Edition. London: Academic Press, 2015.

Seekings, Jeremy. The UDF: A History of the United Democratic Front in South Africa 1983-1991. Cape Town: David Philip Publishers, 2000.

Verdery, Katherine. The Politics of Dead Bodies: Reburial and Postsocialist Change. New York: Columbia University Press, 1999.

Weizmann, Eyal. "Introduction." In Forensis, a project of Forensic Architecture, 9-32. Berlin: Sternberg Press and Forensic Architecture, 2013. 